\title{
Assessment of Chromium Contamination in the Monte Alegre Stream: a Case Study
}

\author{
Juliano José Corbi ${ }^{1,2 *}$, Felipe André dos Santos ${ }^{2}$, Ricardo Zerlin ${ }^{2}$, Ademir dos Santos ${ }^{3}$, \\ Claudio Gilberto Froehlich ${ }^{1}$ and Susana Trivinho-Strixino ${ }^{4}$ \\ ${ }^{I}$ Departamento de Biologia; Faculdade de Filosofia Ciências e Letras; Universidade de São Paulo; Ribeirão Preto \\ - SP - Brasil. ${ }^{2}$ Departamento de Ciências Biológicas e da Saúde; Centro Universitário de Araraquara; 14801-340; \\ Araraquara - SP - Brasil. ${ }^{3}$ Departamento de Química Analítica; Instituto de Química de Araraquara; Universidade \\ Estadual Paulista; 14800-970; C.P.: 355; Araraquara - SP - Brasil. ${ }^{4}$ Departamento de Hidrobiologia; \\ Universidade Federal de São Carlos; 13560-970; C.P.: 676; São Carlos - SP - Brasil
}

\begin{abstract}
The aim of this work was to study the contamination by chromium in the sediments of the Monte Alegre stream and in the larvae of Odonata and the possible impact caused by them on the stream macroinvertebrates community. It was found that chromium contaminated the sediments and the aquatic biota. Although, the stream macroinvertebrates community structure did not appear to be modified.
\end{abstract}

Key words: stream macroinvertebrates; contamination; chromium

\section{INTRODUCTION}

Among the aquatic pollutants, heavy metals are the most appropriate indicator of pollution, because of their stability in sediments and scarcity in natural environments (Saiki et al., 2001). Potentially toxic metals introduced into aquatic environments by industrial, domestic and other human activities are absorbed and concentrated in the sediments (Du et al., 2007; Corbi et al., 2006) and in food chains (Notten et al., 2005; Schroder, 2005) causing mortality of the aquatic biota (Saiki et al., 2001). Metal accumulation in the sediments results in serious environmental problems to the surrounding areas, affecting the water quality and bioassimilation and bioaccumulation of metals by the aquatic organisms. As a consequence, potential long-term implications on human health and on the ecosystems are expected (Mertz, 1986; Ip et al., 2007; Corbi et al., 2008).

In the aquatic environment, sediments are the most significant physical pool of metals and may contribute significantly to its concentrations in stream macroinvertebrates, either by absorption/adsorption from terrestrial water or by direct ingestion (Clements, 1991; Pourang, 1996). Metal contamination of sediments resulting from urban runoff exerts a deleterious impact on freshwater macroinvertebrates, particularly the loss of metal sensitive orders such as Ephemeroptera (mayflies), Plecoptera (stoneflies) and Trichoptera (caddisflies) (Karouna-Renier and Sparling, 2001; Corbi and Trivinho-Strixino, 2008).

Chromium is rarely found in natural waters (Mertz, 1986), but it can occur as a contaminant of

*Author for correspondence: julianocorbi@yahoo.com.br 
waters from the leather industry activities. It is also used as a micronutrient in the fertilizers for sugar cane cultivation (Angelotti-Neto et al., 2004; Alcântara and Camargo, 2001; Batalha and Parlatore, 1993; Canto, 1997). In atmospheric air, the concentrations of chromium are about $0.1 \mu \mathrm{g} / \mathrm{m}^{3}$; in non-impacted rivers the concentrations are about $1.0 \mu \mathrm{g} \mathrm{kg}^{-1}$ and in marine waters, the concentrations are about 1.0 to $10 \mu \mathrm{gg}^{-1}$. In potable water, the permitted levels of chromium are $50 \mu \mathrm{g} \mathrm{kg}^{-1}$ (WHO, 1988). The vast majority of chromium in surface water may come from the particulate material in the sediments (ATSDR, 2000). In soils, the reference values are of $40 \mathrm{mg} \mathrm{kg}^{-1}$ and the prevention values are 75 $\mathrm{mg} \mathrm{kg}^{-1}$. A study conducted by Leslie et al., (1999) demonstrated that extreme chromium contamination had an adverse effect on aquatic life in a lotic system, both at the community level (reducing diversity) and at the level of individuals (sublethal effects on surviving individuals).

In 2001, 150 tons of leather residues had been incorporated in the soil as a source of organic matter on the Monte Alegre Farm. These residues originating from the leather industry and contained high concentrations of chromium, were irregularly used as soil fertilizer by the farmers for mango, sugar-cane, coffee, orange, corn and lemons, contaminating the soils (Santos et al., 2009).

Monte Alegre stream, located near Monte Alegre farm, receives chromium from the runoff process. The aim of this work was to study the possible contamination of the sediments and of Odonata larvae by chromium in the Monte Alegre stream. We also analyzed the possible impact caused by the contamination on the stream macroinvertebrates community structure.

\section{MATERIAL AND METHODS}

\section{Study site}

Monte Alegre Farm is located in Bueno de Andrade municipality in the State of São Paulo, Brazil (Fig. 1). The low order Monte Alegre stream is located near Monte Alegre Farm in a preserved area between the coordinates $21^{\circ} 34^{\prime}(\mathrm{S})$ $48^{\circ} 11^{\prime}(\mathrm{W})$ and $21^{\circ} 34^{\prime}(\mathrm{S}) 48^{\circ} 12^{\prime}(\mathrm{W})$ in the Mogi-Guaçu River basin (URGH9). The stream has low water velocity $(<2 \mathrm{~m} / \mathrm{s})$, low depth $(<0.8 \mathrm{~m})$ and width $(<1.5 \mathrm{~m})$ and is located at low altitude, (about $570 \mathrm{~m}$ ). The stream is within a Cerrado area and has predominantly sand substrates (fine and coarse, $70 \%$ of the total). The substrates are also composed of litter and wood debris. The dissolved oxygen varied from 8.1 to $9.4 \mathrm{mg} / \mathrm{L}, \mathrm{pH}$ from 6.85 to 7.01 , electric conductivity from 0.026 to 0.028 $\mathrm{mS} / \mathrm{cm}$ and temperature from 22.3 to $23.6^{\circ} \mathrm{C}$. The wet season occurs between October and March, while the dry season occurs from April to September (Ometto et al., 2000). The stream is free from other anthropic impacts such as industrial, domestic or mining activities. Physical and chemical variables of water $(\mathrm{pH}$, temperature, dissolved oxygen and electric conductivity) were measured in situ, by using a Yellow Springs multimeter, model 556.

\section{Sampling and storage}

Sediments and stream macroinvertebrates were collected in two points apart by $2.2 \mathrm{~km}$ distance; downstream (impacted area) between the coordinates $21^{\circ} 34^{\prime}(\mathrm{S}) 4^{\circ} 11^{\prime}(\mathrm{W})$ and upstream (reference area) between the coordinates $21^{\circ} 34^{\prime}(\mathrm{S})$ $48^{\circ} 12^{\prime}(\mathrm{W})$.

Sediments for chromium analysis were sampled in triplicate using a standard Ekman-Birge grab in a sampling area of $255 \mathrm{~cm}^{2}$. Samples were taken twice at each site in June, 2006 and February, 2007. Sediments were stored at $4^{\circ} \mathrm{C}$ until testing as proposed by Santos (1999). Larvae of Odonata were collected using a D-frame (Merrit and Cummins, 1996) aquatic net (mesh sieve $250 \mu \mathrm{m}$ ) and sampled exhaustively until there was enough biomass (at least $0.10 \mathrm{~g}$ dry weight) for laboratory analysis. Larvae retained in the net were transferred to acid-washed polypropylene bags and stored with ice during transportation to the laboratory, according to the methodology described by Pourang (1996). 


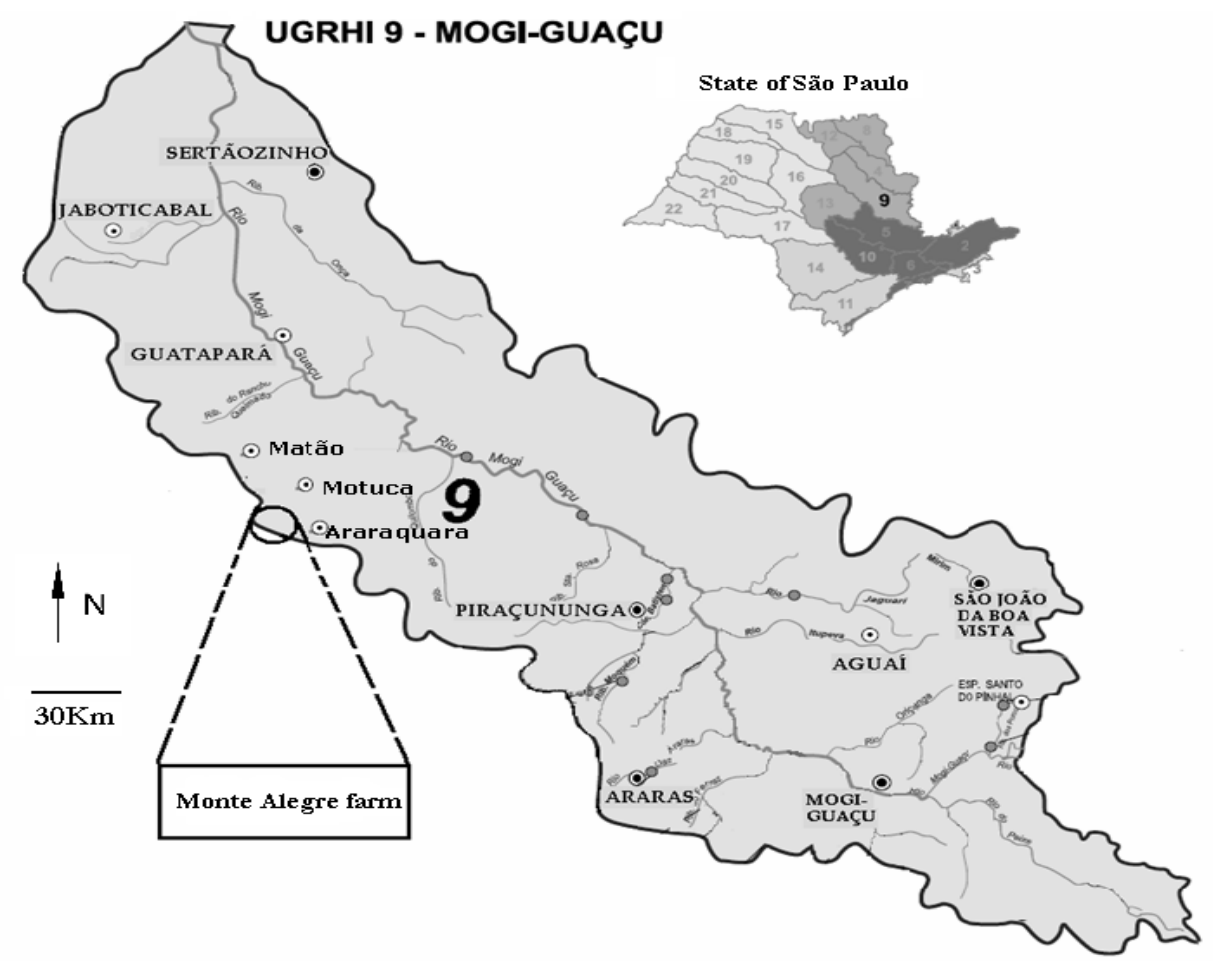

Figure 1 - Location of the sampling sites on Monte Alegre Farm, (Moji-Guaçu river basin), State of São Paulo, Brazil. (Reference: Santos et al., 2009).

Macroinvertebrates were surveyed in two periods: June, 2006 and February, 2007. The macroinvertebrates were collected using a D-frame (Merrit and Cummins, 1996) aquatic net $(250 \mu \mathrm{m})$ including riffle and pool areas for five minutes as recommended by Fontoura (1985). Two collections were combined into a single sample at each point. Samples were transferred to the laboratory, washed in a $0.21 \mathrm{~mm}$ mesh sieve, selected on an illuminated tray and fixed with $70 \%$ alcohol. Insects were dominant and for most of them taxonomic identification was made to family level, based on available keys (Brinkhurst and Marchese, 1991; Merritt and Cummins, 1996). Based on the study conducted by Corbi and Trivinho-Strixino (2006), family identification appeared to be good for monitoring the effects of land uses on stream macroinvertebrate communities in low order streams.

Three sediment sub-samples were collected from the streams for the organic matter determination.

\section{Analytical procedures}

Deionized double distilled water (DDDW) was used for the analysis. All acids were purchased from Merck® (analytical grade). The materials used during the experiments were previously washed with concentrated nitric acid as described before (Tschöpel et al., 1980).

Sediment samples for the metals determination were oven dried at $65{ }^{\circ} \mathrm{C}$ on glass dishes, homogenized using a pestle and mortar and each of the weighed samples (about $2.0 \mathrm{~g}$ ) was taken to a $100 \mathrm{~mL}$ be beaker to which $5.0 \mathrm{~mL}$ of $\mathrm{HNO}_{3}$ was added and digested near dryness at $90{ }^{\circ} \mathrm{C}$ on a hot plate. The digested samples were cooled at room temperature, filtered by using filter papers and collected in $100 \mathrm{~mL}$ beaker. The filter papers were washed with ca. $20 \mathrm{~mL}$ of water and the contents of the beaker were transferred to $100 \mathrm{~mL}$ volumetric flasks. The solutions were analyzed for metals in a Pye Unicam flame atomic absorption spectrophotometer. Analyses and digestions were undertaken in triplicate (De Paula and Mozeto, 2001).

Frozen Odonata larvae were thawed at room temperature. Larvae were pooled to obtain at least $0.10 \mathrm{~g}$ of dry weight. Digestion was performed in a similar way used for the sediment analyses. The cooled digested samples were transferred to 5.0 $\mathrm{mL}$ volumetric flasks (Pourang, 1996). Pooled samples were analyzed by graphite furnace AAS 
(model SHIMADZU ASC-6100). Analyses and digestions were undertaken in triplicate.

Organic matter content was determined by mass loss after ignition $\left(550^{\circ} \mathrm{C}, 4\right.$ hours $)$ in dry fractions of the sediments (dried in a stove at $60^{\circ} \mathrm{C}$ for $12 \mathrm{~h}$ ) as described by Maitland (1979). Granulometric analyses of the sediments were made using the Biota-FAPESP protocol (São Paulo State Research Foundation, Brazil), (Process number 2003/105179).

\section{Data analysis}

Sediments and Odonata larvae

Differences for each chromium data set (chromium concentration in the larvae of Odonata and in the sediments of the stream) were tested using the Mann-Whitney test. The differences were considered significant if $p<0.05$. The MannWhitney analysis was performed using GraphPad InStat version 3.00, GraphPad Software.

\section{Stream macroinvertebrates community}

The stream macroinvertebrates were analyzed by the participation of each taxonomic group and by the total organisms collected. Stream macroinvertebrates were analyzed considering the relative participation in three macroinvertebrates classes, according to Corbi and Trivinho-Strixino (2002). In order to evaluate the integrity of each stream, the community characteristics were determined by the following metrics: richness index (Margalef), diversity index (Shannon), dominance (Pielou), BMWP (with regional adaptations) and Belgian Biotic Index, EPT percentage (Ephemeroptera, Plecoptera and Trichoptera), ratio (\%) of the number of EPT families by the total number of macroinvertebrate families (EPT/total of families $X$ 100), ratio between the number of EPT (sensitive) and Chironomidae (tolerant) (EPT/Chironomidae X 100) and ratio between the Chironomidae number and the total of individuals collected (Chironomidae/total X 100). The PAST Program (Version 1.68) was used to calculate the richness index (Margalef), dominance and the diversity index (Shannon) (Hammer, 2001).

\section{RESULTS}

\section{Sediments and Odonata larvae}

The results showed high concentrations of chromium in the sediments of the Monte Alegre stream which suggested that chromium contaminated the aquatic sediments. In the downstream area (impacted area), chromium concentrations were three times higher than those found in the upstream area (reference area). In the downstream area, the concentrations varied from 30.1 to $32.4 \mathrm{mg} \mathrm{kg}^{-1}$ and in the upstream area, the concentrations varied from 8.02 to $10.93 \mathrm{mgkg}^{-1}$. The larvae of Odonata were also affected by the sediment contamination. In the downstream area, the concentrations varied from 0.64 to $0.72 \mathrm{mg} \mathrm{kg}$ 1 and in the upstream area the concentrations varied from 0.42 to $0.46 \mathrm{mg} \mathrm{kg}^{-1}$ (Table 1). The Mann-Whitney test, applied for metal concentrations in the sediments, showed significant differences in the concentrations of chromium between the upstream and downstream areas.

Table 1 - Concentrations of chromium detected in the sediments and in the larvae of Odonata for Monte Alegre stream in the two sampling areas. * Minimum and maximum values for the period of study.

\begin{tabular}{lccc}
\hline & Upstream* & Downstream* & Ref. \\
\hline Sediments & $8.02-10.9$ mg.kg-1 & $30.1-32.4$ mg.kg-1 & 40 mg.kg-1 \\
Larvae of Odonata & $0.42-0.46$ mg.kg-1 & $0.64-0.72$ mg.kg-1 & $* *$ \\
\hline
\end{tabular}

Ref: Reference values for soils (Conama resolution, 357).

** Without reference values

\section{Stream macroinvertebrates community}

In this study, 21 families of stream macroinvertebrates were identified (Table 2). The results showed high richness of aquatic macroinvertebrates in Monte Alegre stream (in both the areas), when compared to impacted streams in the state of São Paulo.
In the downstream area (impacted area), the Chironomidae family dominated the stream macroinvertebrates community, with $40 \%$ of the total organisms. In the upstream area (reference area), the Chironomidae contributed with $25 \%$ of the fauna. In the downstream area, other taxonomic groups such as Simuliidae and Elmidae were also observed, with 14 and $11 \%$, respectively 
of the total fauna while in the upstream area, Elmidae with 25\%, Perlidae with $10 \%$ and Corydalidae with $8 \%$ were the other dominant groups. The upstream and downstream areas showed a variety of groups of insects such as Ephemeroptera, Plecoptera and Trichoptera. Some families of EPT such as Perlidae, Polymitarcyidae and Polycentropodidae were observed in the two areas. Odontoceridae and Hydropsychidae (Trichoptera) were observed only in the downstream area (Table 2).

Table 2 - Macroinvertebrates of the Monte Alegre Stream (Bueno de Andrade, São Paulo, Brazil)

\begin{tabular}{|c|c|c|}
\hline Stream macroinvertebrates & Upstream & Downstream \\
\hline \multicolumn{3}{|l|}{ Odonata } \\
\hline Calopterygidae & O & 0 \\
\hline Gomphidae & 0 & 0 \\
\hline Libellulidae & 0 & $\diamond$ \\
\hline Hemiptera & & \\
\hline Gerridae & 0 & \\
\hline Plecoptera & & \\
\hline Perlidae & $\bullet$ & \\
\hline Megaloptera & & \\
\hline Corydalidae & $\diamond$ & \\
\hline Coleoptera & & \\
\hline Elmidae & - & $\diamond$ \\
\hline Gyrinidae & & 0 \\
\hline Hydrophilidae & & 0 \\
\hline Limnichidae & 0 & 0 \\
\hline Syrtidae & 0 & \\
\hline Ephemeroptera & & \\
\hline Leptohyphidae & 0 & 0 \\
\hline Leptophlebiidae & O & 0 \\
\hline Polymitarcyidae & 0 & \\
\hline Trichoptera & & \\
\hline Hydropsychidae & & $\diamond$ \\
\hline Odontoceridae & & $\diamond$ \\
\hline Polycentropodidae & 0 & \\
\hline Díptera & & \\
\hline Ceratopogonidae & & 0 \\
\hline Chironomidae & - & - \\
\hline Simuliidae & 0 & $\diamond$ \\
\hline Oligochaeta & & \\
\hline Naididae & $\diamond$ & $\bullet$ \\
\hline Total & 95 & 118 \\
\hline $20<\bullet<50$ & $5<\diamond<20$ & $O<5$ Specimes \\
\hline
\end{tabular}

The values of the community index (richness index Margalef - IMg, diversity index Shannon $H^{\prime}$ and families richness $-F$ ) could be considered high in both the areas. In the upstream area, the values of these indexes were slightly higher than those found downstream. The dominance index was smaller in the upstream area when compared to the downstream area. The biotic indexes (BMWP and IBB) applied to the macroinvertebrates taxa of the two areas demonstrated excellent water quality in the upstream area and good water quality in the downstream area (Table 3 ).

\section{Organic matter contents}

The organic matter contents were relatively low for the two areas of the stream. Values varied from 5 to $20 \%$. The highest value was detected for the downstream area with $20 \%$ of organic matter content (Esteves, 1988). 
Table 3 - Summary of the main community characteristics and evaluation measurements of the two sampling areas (upstream and downstream).

\begin{tabular}{lcc}
\hline Community metrics & Upstream & Downstream \\
\hline Number of families - F & 16 & 15 \\
(Chironomidae/total) x 100 & 25 & 40 \\
EPT (\%) & 15 & 16 \\
(EPT/Chironomidae) x 100 & 68 & 42 \\
(n fam. EPT/total fam.) x 100 & 32 & 26 \\
Diversity index Shannon (H') & 2.3 & 2.0 \\
Richness index Margalef ( $\mathrm{I}_{\mathrm{Mg}}$ ) & 3.3 & 2.9 \\
Dominance & 0.15 & 0.20 \\
Biotic index (BMWP) & 87 & 69 \\
Biotic index (IBB) & 7.0 & 5.0 \\
\hline
\end{tabular}

\section{DISCUSSION}

According to the results obtained by Santos et al. (2009), the soils were contaminated with different concentrations of chromium depending on the agricultural activity of the farmers. In general, the concentrations varied from 35 to $50 \mathrm{mg} \mathrm{kg}^{-1}$.

As has been described by Mozeto et al. (2006), there are reference values for the evaluation of the quality of sediments. For chromium, the threshold effect levels (TEL) and probable effect level (PEL) are 37.3 and $90.0 \mathrm{mg} \mathrm{kg}^{-1,}$ respectively. Toxicity rarely occurs below the TEL level but it occurs frequently above the PEL, and if it is between the two levels, toxicity may occur (Muniz et al., 2004). Thus, although the concentrations of chromium downstream were significantly higher than upstream, both the areas were below the threshold effect level. These values, lower than the TEL and the PEL levels, were probably related to the capacity of the organic substance and mineral fraction in holding back metals. The low values of organic matter detected in the sediments and the homogeneous substrate (sand substrates) observed in the stream suggested that these variables influenced at the low concentrations of metals (TEL and PEL values) in the sediment and in aquatic insects. As pointed out by Santos et al. (2009), the organic matter content exerted important functions in the linking of $\mathrm{Cr}$ in the soils.

With these results, it could be infered that the mobility of chromium from the soils to the waters and sediment of Monte Alegre stream was low. This fact probably contributed to the reduction of the contamination of Odonata larvae. Although with low concentrations, the major concentration of chromium observed for the larvae downstream could represent an important link in the transference of the metals to the upper trophic levels, such as birds, mammals and other organisms.

The inputs from the riparian sources, in the form of dissolved organic matter, leaf litter, fruits, woody debris and invertebrates, are recognized as important food resources for aquatic food webs in many systems (Lynch et al., 2002). Several studies have shown the importance of the riparian canopy for the stream macroinvertebrate community's distribution (Ferreira-Peruquetti and FonsecaGessner, 2003; Benstead and Pringle, 2004; Goulart and Callisto, 2005). Bojsen and Jacobsen (2003) and Kay et al. (2001) showed that the reduction of the riparian canopy caused a decrease in litter detritus on the streambed and an increase in periphyton biomass, because of the light-related factors. In these streams, the macroinvertebrate communities were homogeneous and depauperate, in contrast to those found in the forested areas. The present results clearly showed the importance of the riparian vegetation, which permitted, in the two stations (upstream and downstream), a great taxa richness when compared to impacted streams in the state of São Paulo (Corbi and TrivinhoStrixino, 2008). The results confirmed that the contamination of the sediments was higher downstream when compared to the upstream area, but the stream macroinvertebrates were very similar at the two stations. Although similar, the upstream area presented some sensitive taxa such as Plecoptera, which were not present in the downstream area.

Many streams in São Paulo are located in a Cerrado vegetation area at low altitudes and with sand substrates. As a result, the dominance of Chironomidae is observed (Roque and TrivinhoStrixino, 2001; Freire and Gessner, 2002). This was also observed in the present study, where the 
Chironomidae dominated in the two studied areas. At the same time, the community index gave consistent information about the faunistic characteristics and integrity of the two areas of the Monte Alegre stream. Great taxa richness, added to the similar number of families collected and percentage of EPT groups, in addition to a high ratio between the sensitive and tolerant taxa (EPT/Chironomidae) found in the two stations, showed the importance of riparian vegetation for macroinvertebrates composition in the two areas. Thus, further studies would be needed for detecting the efficiency of different insect groups to tolerate different metals in aquatic environments, as suggested by Nummelin et al. (2007) and Corbi et al. (2010) when studying different species of aquatic insects in impacted streams. The results also demonstrated the importance of the preservation of riparian vegetation for the stream macroinvertebrate community's distribution, which appeared to be the most important factor influencing the composition of these aquatic fauna and were responsible for absorption of toxic products which came from the neighboring cultivated areas (Corbi, et al., 2010).

\section{ACKNOWLEDGEMENTS}

We would like to thank Professor Pedro P. Corbi and Dra. Vanessa Colombo-Corbi for valuable suggestions made during the research. Financial support was granted by FAPESP (São Paulo State Research Foundation, Brazil), (Process numbers 2006/61400-2 and 2003/10517-9).

\section{REFERENCES}

Alcantâra, M.A.K. and Camargo, O.A. (2001), Transporte de crômio trivalente influenciado pelo $\mathrm{pH}$, horizonte do solo e fontes do crômio. R. Bras. Eng. Agríc. Ambiental, 5, 497.

[ATSDR] Agency for Toxic Substances and Disease Registry. (2000), Toxicological profile for chromium. Syracuse: U.S. Department of Health and Human Services,

Angelotti-Netto, A.; Crestana, S.; De Oliveira, S.C. and Barbosa, R.V.R. (2004), Metais pesados provenientes de atividade agrícola: formas, prevenção e controle. In: Espíndola, E.L.G., Wendland, E. (Eds.), Bacia Hidrográfica. Rima Editora, São Carlos, pp 1-14.
Batalha, B. L. and Parlatore, A. C. (1993), Controle da qualidade da água para consumo humano. São Paulo, Cetesb.

Benstead, J.P. and Pringle, C.M. (2004), Deforestation alters the resource base and biomass of endemic stream insects in eastern Madagascar. Freshwater Biol., 49, 490-501.

Bojsen, B.H. and Jacobsen, D. (2003), Effects of deforestation on macroinvertebrate diversity and assemblage structure in Ecuadorian Amazon streams. Arch. für Hydrobiol., 158, 317-342.

Canto, E. L. (1997), Minerais, minérios e metais: de onde vem para onde vão? Moderna, São Paulo.

Clements, W.H. (1991), Community Responses of Stream Organisms to Heavy Metals. Univ. Press. Colorado.

Corbi, J.J. and Trivinho-Strixino, S. (2002), Spatial and bathimetric distribution of the macrobenthic fauna of the Ribeirão das Anhumas reservoir (Américo Brasiliense - SP, Brazil). Acta Limnol. Bras., 14(1): $35-42$.

Corbi, J.J.; Trivinho-Strixino, S.; Dos Santos, A. and Del Grande, M. (2006), Environmental diagnostic of metals and organochlorated compounds in streams near sugar cane plantations activity (State of São Paulo, Brazil). Quim. Nova, 29, 61-65.

Corbi, J.J. and Trivinho-Strixino, S. (2006), Influence of taxonomic resolution of stream macroinvertebrate communities on the evaluation of different land uses. Acta Limnol. Bras., 18(4):469-475.

Corbi, J.J.; Trivinho-Strixino, S. and Dos Santos, A. (2008), Environmental evaluation of metals in sediments and dragonflies due to sugar cane cultivation in Neotropical streams. Wat. Air Soil Pollu., 195, 325-333.

Corbi, J.J. and Trivinho-Strixino, S. (2008), Relationship between sugar cane cultivation and stream macroinvertebrate communities: a study developed in the southeast of Brazil. Braz. arch. biol. Technol 51(4), 769-779.

Corbi, J.J.; Froehlich, C.G.; Trivinho-Strixino, S. and Dos Santos, A. (2010), Bioaccumulation of metals in aquatic insects of streams located in areas with sugar cane cultivation. Quim. Nova, 33, 644-648.

De Paula, F.C.F. and Mozeto, A.A. (2001), Biogeochemical evolution of trace elements in a pristine watershed at the Brazilian southeastern coast. Appl. Geochem., 16, 1139-1151.

Du, J.Z.; Mu, H.D.; Song, H.Q.; Yan, S.P.; Gu, Y.J. and Zhang, J. (2007), 100 years of sediment history of heavy metals in Daya Bay, China. Wat. Air Soil Pollu., 190, 343-351.

Esteves, F.A. (1988). Fundamentos de Limnologia. Interciência - Finep, Rio de Janeiro. 545p.

Ferreira-Peruquetti, P. and Fonseca-Gessner, A.A. (2003), Odonata community on natural areas of Cerrado and monoculture of northeastern São Paulo 
State, Brazil: relationship between land use and richness. Revta. bras. Zool., 20, 219-224.

Fontoura, A.P. (1985), Manual de vigilância da qualidade das águas superficiais. Avaliação biológica da qualidade da água. Instituto de zoologia "Dr. Augusto Nobre". Faculdade de Ciências Universidade do Porto. Porto - Portugal, 38 pp.

Freire, C.F. and Fonseca-Gessner, A.A. (2002), Larvas de Chironomidae (Diptera) na microbacia do Ribeirão Canchim, São Carlos, SP, Brasil. Entomol. y Vect., 8, 17-429.

Goulart, M. and Callisto, M. (2005), Mayfly diversity in the Brazilian tropical headwaters of Serra do Cipó. Braz. arch. biol. Technol., 48, 983-996.

Hammer, O.; Harper, D.A.T. and Ryan, P.D. (2001), PAST; Paleontological Statistics software package for education and data analysis, Paleontologia eletronica.

Ip, C.C.M.; Li, X.D.; Zhang, G.; Wai, O.W.H. and Li, Y.S. (2007), Trace metal distribution in sediments of the Pearl River Estuary and the surrounding coastal area, South China. Envir. Pollut., 147, 311-323.

Karouna-Renier, N.K. and Sparling, D.W. (2001), Relationships between ambient geochemistry, watershed land-use and trace metal concentrations in aquatic invertebrates living in stormwater treatment ponds. Envir. Pollut., 112, 183-192.

Kay, W.R.; Halse, S.A.; Scanlon, M.D. and Smith, M.J. (2001), Distribution and environmental tolerances of aquatic macroinvertebrate families in the agricultural zone of southwestern Australia. J. N. Am. Benthol. Soc., 20, 182-199.

Leslie, H.A.; Vaate, P. and Kraak, M.H.S. (1999), Triad assessment of the impact of chromium contamination on benthic macroinvertebrates in the Chusovaya River (Urals, Russia). Arch. Environ. Contam. Toxicol. 37: 182-189

Lima, N.R.W. (1990), Analysis of heavy metals in hydric systems of the Jataí Ecological Station. Acta Limnol. Bras., 3, 1001-1021.

Lynch, R.J.; Bunn, S.E. and Catterall, C.P. (2002), Adult aquatic insects: Potential contributors to riparian food webs in Australia's wet-dry tropics. Austral Ecology, 27, 515-526.

Maitland, P.S. (1979), The distribution of zoobenthos and sediments in Loch Leven, Kinross, Scotland. Arch. für Hydrobiol., 5, 98-125.

Merrit R.W. and Cummins K.W. (1996), An Introduction to the Aquatic Insects of North America. Kendall-hunt, Dubuque, Iowa, USA.

Mertz, W. (1986), Trace Elements in Human and Animal Nutrition. Fifth ed. Academic Press, London.

Mozeto, A. A.; Umbuzeiro, G. A. and Jardim, W. F. (2006), Métodos de Coleta, Análises Físico-Químicas e Ensaios Biológicos e Ecotoxicológicos de Sedimentos de Água Doce. 1st ed., Cubo: São Carlos.

Muniz, P.; Venturini, N. and Gómez-Erache, M. (2004), Spatial distribution of chromium and lead in the benthic environment of coastal areas of the Río de La Plata Estuary (Montevideo, Uruguay). Braz. J. Biol., 64 (1): 103-116.

Notten, M.J.M.; Oosthoek, A.J.P.; Rozema, J. and Aerts, R. (2005), Heavy metal concentrations in a soil-plant-snail food chain along a terrestrial soil pollution gradient. Envir. Pollut., 138, 178-190.

Nummelin, M.; Lodenius, M.; Tulisalo, E.; Hirvonen, H. and Alanko, T. (2007), Predatory insects as bioindicators of heavy metal pollution. Envir. Pollut., 145, 339-347.

Ometo, J.P.H.B.; Martinelli, L.A.; Ballister, M.V.; Gessner A.; Krische, A.V. and Victoria, R.L. (2000), The effects of land use on water chemistry and macroinvertebrates rates in two streams of the Piracicaba river basin South-east Brazil. Freshwater Biol., 44, 327-337.

Pourang, N. (1996), Heavy metal concentrations in surficial sediments and benthic macroinvertebrates from Anzali wetland, Iran. Hydrobiologia, 331, 5361.

Rocha, J.C. and Rosa, A.H. (2003), Substâncias Húmicas Aquáticas: Interação com Espécies Metálicas. São Paulo. Editora Unesp.

Roque, F.O. and Trivinho-Strixino, S. (2001), Benthic macroinvertebrates in mesohabitats of different spatial dimensions in a first order stream (São CarlosSP). Acta Limnol. Bras., 13, 69-77.

Saiki, M.K.; Martin, B.A.; Thompson, L.D. and Welsh, D. (2001), Copper, Cadmium, and Zinc concentrations in juvenile Chinook Salmon and selected fish-forage organisms (aquatic insects) in the upper Sacramento River, California. Wat. Air Soil Pollu., 132: 127-139.

Santos, A., (1999), Distribuição de metais no reservatório de captação de água superficial Anhumas Américo Brasiliense - SP. USP. PhD Thesis, Universidade de São Paulo (USP).

Santos, A.; Oliveira, L.C.; Botero, W.G.; Mendonça, A.G.R.; Dos Santos, F.A.; Rocha, J.C.; Ribeiro, M.L. and Oliveira, A.S. (2009), Distribuição e biodisponibilidade de crômio em solos contaminados por resíduos de couro. Quim. Nova (in press).

Schroder, T. (2005), Solide Solution Partitioning of Heavy Metals in Floodplain Soils of the Rivers Rhine and Meuse: Field Sampling and Geochemical Modelling. PhD Thesis, Wageningen University, Wageningen.

Tschöpel, P.; Kotz, L.; Shulz, W.; Veber, M. and Tölg, G. (1980), Zur Ursache und Vermeidung systematischer Fehler bei Elementbestimmungen in wäßrigen Lösungen im ng/ml - und pg/ml. Fres. J. Anal. Chem., 302, 1-14.

[WHO] World Health Organization. Chromium. Genova, 1988. 